\title{
Teacher Challenges with Assessment Practices in Elementary School Physical Education: A Literature Review
}

\author{
Jongho Moon \\ University of South Carolina
}

\section{Introduction}

Elementary school physical education (PE) has historically been recognized as an essential subject in school curricula (Graber et al., 2008; Kirk, 2005). Meaningful experiences of participating in PE have a significant impact on students' development of fundamental motor skills, positive behaviors, and fostering physically active lifestyles (Hunter, 2006; Morgan et al., 2013). Assessment in PE is one of these experiences and has become a central concern in PE pedagogy as it is considered necessary for students to be assessed in order to achieve the desired learning outcomes in school contexts (Elwood, 2006).

Assessment is defined as "the process of gathering, recording, interpreting, using and reporting information about students' progress and achievements in developing knowledge, skills and attitudes" (National Council for Curriculum and Assessment, 2007, p. 7). Siedentop and Tannehill (2000) described PE assessment as "a variety of tasks and settings where students are given opportunities to demonstrate their knowledge, skill, understanding and application of content in a context that allows continued learning and growth" (p. 179).

In PE, assessment is one of the vital components that teachers use to measure student progress toward skill development throughout the learning process (Rink, 2010; Siedentop \& Tannehill, 2000) and use that information to guide instructional practices and enhance student learning (DinanThompson \& Penney, 2015; Shepard, 2008). Moreover, it has the potential to improve pedagogical practices (Wiliam, Lee, Harrison \& Black, 2004). That is, feedback gained through assessment allows teachers to adjust their planning to include what students still need to learn in PE (Fisette \& Franck, 2012; Hay, 2006; Wright \& van der Mars, 2004).

Keywords: assessment, barriers, teacher education

\section{Article History}

Received 18 September 2020

Accepted 23 October 2020

Published 31 October 2020

Available online 31 December 2020

https://doi.org/10.47544/johsk.2020.1.1.16

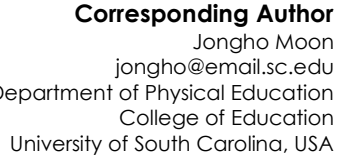

Corresponding Author Jongho Moon jongho@email.sc.edu of Physical Education College of Education

University of South Carolina, USA

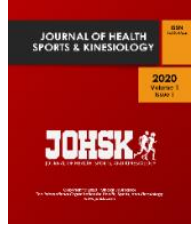

However, studies show that PE teachers expresses concerns that the implementation of assessment takes away from time dedicated to class time and can lead to student misbehavior (Gallo et al., 2006; James, Griffin, \& France, 2005; Lander et al., 2016). Secondary school PE teachers consider assessment unnecessary and perceive it negatively (Kneer, 1986).

Journal of Health Sports \& Kinesiology | ISSN 2692-9864 | www.johsk.com 
In addition, teachers feel they cannot use the assessment properly due to their lack of knowledge (Morgan \& Hansen, 2007). Although research into the impact of assessment has been widely conducted in other disciplines (Wiliam et al., 2004), little efforts have been made to review the research on elementary school PE teachers' challenges in assessment. The purpose of this literature review is to examine teachers' practices and identify the challenges in elementary school PE assessment implementation.

\section{Methods}

A literature search was conducted to identify all published research, in English, that reported teachers' challenges with assessment practices in elementary school PE. The search was conducted using three databases: Google Scholar, PubMed, and Educational Resources Information Center (ERIC). These were selected because they are three of the major databases in the field of education. In searching for the data, multiple combinations of the following key terms were used: "physical education", "assessment", "evaluation", "elementary", "practice*", "barrier*", "difficult*", and "challenge*". The search yielded a total of 846 unique records, which were screened by title, then by abstract, and finally by full text, resulting in 8 records that were obtained for the review. The data were qualitatively synthesized using a thematic analysis (Thomas \& Harden, 2008). Specifically, the researchers independently searched for the teachers' challenges and/or barriers to assessment practices in PE. Lastly, the researchers examined the list for redundancies and similarities and grouped all challenges thematically (see Table 1).

Table 1. Themes and Factors of Teachers' Challenges with Assessment Practices

\begin{tabular}{|c|c|c|c|}
\hline Themes & & Factors & Sources \\
\hline \multirow[t]{5}{*}{$\begin{array}{r}\text { Perceived Barriers to } \\
\text { Assessment } \\
\text { Practices }\end{array}$} & 1. & $\begin{array}{l}\text { Lack of time (e.g., management, } \\
\text { planning, scheduling, school } \\
\text { disruptions, etc.) }\end{array}$ & $\begin{array}{l}\text { Lander et al. (2016); Matanin \& Tannehill, (1994); } \\
\text { Morgan \& Hansen, (2007) }\end{array}$ \\
\hline & 2. & Lack of assessment knowledge & $\begin{array}{l}\text { Lander et al. (2016); Morgan \& Hansen, (2007); } \\
\text { Richard et al. (1999) }\end{array}$ \\
\hline & 3. & $\begin{array}{l}\text { Lack of confidence (e.g., teacher } \\
\text { readiness, ability to implement, } \\
\text { etc.) }\end{array}$ & $\begin{array}{l}\text { Morgan \& Hansen, (2007); } \\
\text { Patton \& Griffin, (2008) }\end{array}$ \\
\hline & 4. & $\begin{array}{l}\text { Lack of training (access to } \\
\text { professional development) }\end{array}$ & $\begin{array}{l}\text { Matanin \& Tannehill, (1994); } \\
\text { Morgan \& Hansen, (2007) }\end{array}$ \\
\hline & 5. & $\begin{array}{l}\text { Impracticality (e.g., large class } \\
\text { size, increase workload, } \\
\text { unfairness) }\end{array}$ & $\begin{array}{l}\text { Landers et al. (2016); Patton \& Griffin, (2008); } \\
\text { Richard et al. (1999) }\end{array}$ \\
\hline \multirow[t]{3}{*}{$\begin{array}{r}\text { Value of Assessment } \\
\text { Practices }\end{array}$} & 6. & $\begin{array}{l}\text { Low priority compared to other PE } \\
\text { curricula (physical activity) }\end{array}$ & $\begin{array}{l}\text { James et al. (2005); Patton \& Griffin, (2008); } \\
\text { Richard et al. (1999) }\end{array}$ \\
\hline & 7. & $\begin{array}{l}\text { Students' lack of engagement } \\
\text { (e.g., low motivation, inactivity, } \\
\text { enjoyment) }\end{array}$ & $\begin{array}{l}\text { Matanin \& Tannehill, (1994); } \\
\text { Morgan \& Hansen, (2007) }\end{array}$ \\
\hline & 8. & Increase in student misbehavior & $\begin{array}{l}\text { Patton \& Griffin, (2008); } \\
\text { Richard et al. (1999) }\end{array}$ \\
\hline \multirow[t]{2}{*}{$\begin{array}{r}\text { Assessment } \\
\text { Practices } \\
\text { within School } \\
\text { Environments }\end{array}$} & 9. & $\begin{array}{l}\text { Lack of administrative support } \\
\text { (administrators, principal \& school } \\
\text { board) }\end{array}$ & $\begin{array}{l}\text { Chróinín \& Gosgrave, (2013); } \\
\text { Hastie \& Siedentop, 2006; James et al. (2005); } \\
\text { Matanin \& Tannehill, (1994); Morgan \& Hansen, (2007); } \\
\text { Patton \& Griffin, (2008); Richard et al. (1999) }\end{array}$ \\
\hline & 10. & Low student support & James et al. (2005) \\
\hline
\end{tabular}

\section{Journal of Health Sports \& Kinesiology | ISSN 2692-9864 | www.johsk.com}


| 2020 | Volume 1 | Issue 1 | The Journal of Health, Sports, and Kinesiology |

\section{Results}

\section{Perceived Barriers to Assessment Practices}

Studies illustrate that PE teachers perceived assessments as being time-consuming, being impractical with large class sizes, creating too much work for both teachers and students, and taking the enjoyment out of PE (Lander et al., 2016; Morgan \& Hansen, 2007). Other studies indicate that PE teachers feel they have not been adequately trained to assess students' performances of the skills they learn in class (Matanin \& Tannehill, 1994; Morgan \& Hansen, 2007). Moreover, PE teachers do not know how to appropriately use assessments due to their lack of knowledge about assessment design and delivery (Lander et al., 2016; Morgan \& Hansen, 2007). Additionally, students resist assessments as they feel assessments' practices are unclear and fail to underscore the learning outcomes that they should achieve in PE (Richard et al., 1999).

\section{Value of Assessment Practices}

Literature shows that teachers did not value assessment as an essential component in PE and perceived there to be a negative connection between assessment and students' behavior (Patton \& Griffin, 2008). For instance, Matanin and Tannehill (1994) described that PE teachers stated that it was more important to keep the students busy than to assess students' progress because assessment inhibits student enjoyment. Similarly, Richard et al. (1999) presented that teachers temporarily discredit assessment since these practices increased student misbehavior and decreased student motivation due to inactivity during assessment.

\section{Assessment Practices within School Environments}

Research describes that school contexts (e.g., classroom ecology, other teachers, administrators, environment, etc.) influence PE teachers' implementation of assessment (Hastie \& Siedentop, 2006; James et al., 2005). For instance, Hay and Penney (2013) discuss assessment practices being impacted by the school environment. Studies show that PE teachers believe that the use of assessment can enhance students, teachers, and administrators' support and value of PE (Chróinín \& Gosgrave, 2013; James et al., 2005). On the other hand, some PE teachers express that they were negatively influenced by other teachers in their department to dismiss assessment practices as inconsequential. This resulted in a decrease in their use of assessment practices (Matanin \& Tannehill, 1994) and that a perceived lack of support and value for PE from school administrators (Morgan \& Hansen, 2007).

\section{Conclusion}

This review adds a comprehensive view of PE teachers' challenges with assessment implementations to the current literature base. In conclusion, researchers have shown that PE teachers face several barriers with regards to implementing assessment practices in PE instruction. These include lack of time, large class sizes, lack of administrative accountability, lack of professional preparation, and belief that assessment is not necessary in PE. Additionally, although the descriptions of assessment practices in PE education have been a feature of education research for a while now, teachers remain incapable of implementing assessment appropriately and are making decisions regarding assessment results without proper training programs (Lund \& Veal, 2008).

\section{Discussion}

Assessments perform an important role in student learning in elementary school contexts. This review was intended to support multiple audiences (i.e., practitioners, teacher educators, and administrators) by discussing barriers teachers have with PE assessment practices. Ideally, based on these findings, teacher educators and schools will provide a teacher education program for professional development to help PE teachers overcome difficulties and allow them to implement effective assessment practices.

\section{References}

Chróinín, D.N., \& Gosgrave, C. (2013). Implementing formative assessment in primary physical education: Teacher perspectives and experiences. Physical Education Sport Pedagogy, 18(2), 218-233.

Journal of Health Sports \& Kinesiology | ISSN 2692-9864 | www.johsk.com 
| 2020 | Volume 1 | Issue 1 | The Journal of Health, Sports, and Kinesiology |

Dinanthompson, M., \& Penney, D. (2015). Assessment literacy in primary physical education. European Physical Education Review, 21 (4), 485-503.

Elwood, J. (2006). Formative assessment: Possibilities, boundaries and limitations. Assessment in Education: Principles, Policy and Practice, 13(2), 215-232.

Fisette, J.L., \& Franck, M.D. (2012). How teachers can use PE metrics for formative assessment. Journal of Physical Education, Recreation \& Dance, 83(5), 23-26.

Gallo, A., Sheehy, D., Patton, K., \& Griffin, L. (2006). Assessment benefits and barriers: What are you committed to? Journal of Physical Education, Recreation \& Dance, 77(8), 46-50.

Graber, K.C., Locke, L.F., Lambdin, D., \& Solmon, M.A. (2008). The landscape of elementary school physical education. The Elementary School Journal, 108(3), 151-160.

Hastie, P.A., \& Siedentop, D. (1999). An ecological perspective on physical education. European Physical Education Review, 5(1), 9-30.

Hay, P. (2006). Assessment for learning in physical education. In D. Kirk, D. Macdonald, \& M. O'Sullivan (Eds.), Handbook of physical education (pp. 312-325) London: Sage.

Hay, P., \& Penney, D. (2013). Assessment in physical education: A sociocultural perspective. New York: Routledge.

Hunter, L. (2006). Research into elementary physical education programs. In D. Kirk, D. Macdonald, \& M. O'Sullivan (Eds.), Handbook of physical education (pp. 580-595). London: Sage.

James, A.R., Griffin, L., \& France, T. (2005). Perceptions of assessment in elementary physical education: A case study. Physical Educator, 62(2), 85-95.

Kirk, D. (2005). "Physical education, youth sport and lifelong participation: The importance of early learning experiences." European Physical Education Review, 11 (3), 239-255.

Kneer, M.E. (1986). Description of physical education instructional theory/practice gap in selected secondary schools. Journal of Teaching in Physical Education, 5(2), 91-106.

Lander, N., Morgan, P.J., Salmon, J., \& Barnett, L.M. (2016). Teachers' perceptions of a fundamental movement skill (FMS) assessment battery in a school setting. Measurement in Physical Education and Exercise Science, 20 (1), $50-62$

Lund, J., \& Veal, M. (2013). Assessment-driven instruction in physical education. Champaign, IL: Human Kinetics.

Matanin, M., \& Tannehill, D. (1994). Assessment and grading in physical education. Journal of Teaching in Physical Education, 13(4), 395-405.

Morgan, P.. \& Hansen, V. (2007). Recommendations to improve primary school physical education: Classroom teachers' perspective. The Journal of Educational Research, 101 (2), 99-108.

Morgan, P.J., Barnett, L.M., Cliff, D.P., Okely, A.D., Scott, H.A., Cohen, K.E., \& Lubans, D.R. (2013). Fundamental movement skill interventions in youth: A systematic review and meta-analysis. Pediatrics, 132 (5), e1361-e1383.

NCCA (National Council for Curriculum and Assessment). (2007). Assessment in the primary school curriculum: Guidelines for schools. Dublin: National Council for Curriculum and Assessment.

Patton, K., \& Griffin, L.L. (2008). Experiences and patterns of change in a physical education teacher development project. Journal of Teaching in Physical Education, 27(3), 272-291.

Richard, J.F., Godbout, P., Tousignant, M., \& Grehaigne, J.F. (1999). The try-out of a team sport performance assessment procedure in elementary and junior high school physical education classes. Journal of Teaching in Physical Education, 18, 336-356.

Rink, J. E. (2010). Teaching physical education for learning (6 th ed.). New York: McGraw-Hill.

Siedentop, D., \& Tannehill, D. (2000). Developing teaching skills in physical education (4th ed.). Mountain View, CA: Mayfield.

Shepard, L.A. (2008). Formative assessment: Caveat emptor. In C.A. Dwyer (Ed.), The future of assessment: Shaping teaching and learning (pp. 279-303). New York, NY: Eisbaum.

Thomas, J., \& Harden, A. (2008). Methods for the thematic synthesis of qualitative research in systematic reviews. BMC Medical Research Methodology, 8(1), 45.

Wiliam, D., Lee, C., Harrison, C., \& Black, P. (2004). Teachers developing assessment for learning: impact on student achievement. Assessment in Education, 11 (1), 49-65.

Wright, M., \& van Der Mars. H. (2004). Blending assessment into instruction. Journal of Physical Education, Recreation and Dance, 9(75), 29-35.

Journal of Health Sports \& Kinesiology | ISSN 2692-9864 | www.johsk.com 